\title{
Gambaran Kualitas Hidup Santriwati yang Menderita Skabies di Pondok Pesantren Kecamatan Enam Lingkung Kabupaten Padang Pariaman
}

\author{
Widia Febrina ${ }^{1}$, Nora Harminarti ${ }^{2}$, Hirowati Ali $^{3}$
}

\begin{abstract}
Abstrak
Kualitas hidup terkait dengan kesehatan meliputi aspek fisik, psikis dan sosial. Penilaian kualitas hidup tersebut terdiri dari: tidak ada pengaruh, pengaruh kecil, pengaruh sedang dan pengaruh besar terhadap kualitas hidup karena penyakit skabies. Tujuan: Mengetahui gambaran kualitas hidup santriwati yang menderita skabies di Pondok Pesantren Kecamatan Enam Lingkung, Kabupaten Padang Pariaman. Metode: Jenis penelitian ini adalah deskriptif dengan desain cross sectional. Pondok Pesantren Kecamatan Enam Lingkung Kabupaten Padang Pariaman pada bulan Desember 2019. Pengambilan sampel dilakukan dengan teknik total sampling dengan jumlah sampel sebanyak 32 orang. Data dikumpulkan melalui wawancara, pemeriksaan kulit dan pengerokan kulit. Proses wawancara yang dipandu kuesioner modified Dermatology Life Quality Index yang sudah diterjemahkan dari Bahasa Inggris ke Bahasa Indonesia. Hasil: Mayoritas penyakit skabies berpengaruh kecil terhadap kualitas hidup responden (62,5\%), diikuti dengan pengaruh sedang pada kualitas hidup (25,0\%), selanjutnya tidak ada pengaruh pada kualitas hidup (4\%) dan pengaruh besar pada kualitas hidup (0\%). Komponen kualitas hidup yang paling terganggu adalah kegiatan sekolah/belajar $(18,8 \%)$ dan yang paling tidak terpengaruh adalah hubungan pertemanan $(78,1 \%)$. Simpulan: Mayoritas penyakit skabies memiliki pengaruh yang kecil terhadap kualitas hidup penderita skabies.
\end{abstract}

Kata kunci: modified dermatology life quality index, kualitas hidup, skabies

\section{Abstract}

Quality of life-related to health includes at least physical, psychological and social aspects. The assessment quality of life consists of: no influence, small influence, moderate effect, and large influence on quality of life due to scabies. Objectives: To found out the quality of life in patients with scabies. Methods: The type of research was descriptive with cross-sectional design. Sampling was done by total sampling technique with a total sample of 32 people. Data is collected through interviews with modified dermatology life quality index, skin checks and skin scraping. Results: Majority of scabies had a mild effect on the quality of life of respondents (62.5\%), followed by moderate (25.0\%), no effect (4\%) and severe effect (0\%). The most disturbing quality of life component was school/learning activities (18.8\%), and the least affected were friendships (78.1\%). Conclusion: Majority of scabies has mild effect on the quality of life of scabies sufferers.

Keywords: modified dermatology life quality index, quality of life, scabies

Affiliasi penulis: ${ }^{1}$ Prodi Pendidikan Dokter, Fakultas Kedokteran, Universitas Andalas, Padang, Indonesia. 2. Bagian Parasitologi, Fakultas Kedokteran, Universitas Andalas, Padang, Indonesia. 3. Bagian Biokimia, Fakultas Kedokteran, Universitas Andalas, Padang, Indonesia.

Korespondensi: Nora Harminarti, Email:

noraharminarti@med.unand.ac.id,

Telp: 085216270291

\section{PENDAHULUAN}

Skabies adalah infeksi pada kulit yang disebabkan oleh parasit tungau Sarcoptes scabiei var hominis termasuk ordo acarina. ${ }^{1}$ Penyakit ini masih diabaikan oleh tenaga kesehatan dunia karena tidak mengancam jiwa, namun skabies menyebabkan morbiditas yang cukup berarti bahkan dapat 
menyebabkan kematian akibat infeksi bakteri sekunder. $^{2}$ Penularan skabies bisa terjadi secara langsung maupun tidak langsung melalui alat atau benda yang telah terkontaminasi misalnya penggunaan handuk bersama, memakai sprei penderita skabies dan lain-lain. ${ }^{3}$ Faktor risiko penularan skabies adalah kurangnya kebersihan pribadi dan kondisi lingkungan. ${ }^{4}$ Kondisi lingkungan yang padat, ventilasi kamar yang kurang dan personal hygiene yang buruk memiliki hubungan yang bermakna dengan penyakit scabies. ${ }^{5}$

Skabies dapat diderita oleh siapa saja, menyerang berbagai tingkat sosial ekonomi dan semua tingkat usia karena skabies bersifat kosmopolit. ${ }^{6}$ Anak-anak dan orang tua merupakan populasi yang lebih rentan menderita skabies. World Health Organization (WHO) menyebutkan prevalensi rata-rata $5-10 \%$ pada anak-anak. ${ }^{7}$ Skabies adalah penyakit kulit dengan manifestasi rasa gatal yang hebat terutama pada malam hari sehingga dapat menganggu tidur dan biasanya bersifat kronis. ${ }^{6,8}$ Rasa gatal terutama dirasakan pada tempat-tempat predileksi skabies yaitu, sela-sela jari tangan, di bagian ketiak, alat kelamin, sekitar siku, sekitar puting susu dan pergelangan. ${ }^{9}$ Berdasarkan hasil penelitian Nair et al pada tahun 2016, lesi skabies didapatkan sebanyak $73,52 \%$ di interdigital, $61,76 \%$ di tangan, $60 \%$ di kelamin, dan $57 \%$ di jari. ${ }^{10}$

Secara global, skabies memengaruhi lebih dari 200 juta orang, pada tahun 2014 kejadian skabies didapatkan sebanyak 130 juta. $^{7}$ Menurut Internasional Alliance for the Control Of Scabies (IACS), dalam literatur terbaru kejadian skabies cukup bervariasi yakni $0,3 \%$ - 46\%. ${ }^{11}$ Berdasarkan data dari Global Burden of Disease tahun 2015, skabies menduduki posisi 101 dalam Disability Adjusted Life Years (DALY) global berstandar usia dari 246 kondisi. $^{12}$ Secara global skabies menyebabkan 0,21 \% DALY. ${ }^{13}$

Skabies sebagian besar ditemukan di negara berkembang. ${ }^{7}$ Mesir merupakan salah satu negara berkembang yang belum terbebas dari skabies. Berdasarkan hasil penelitian kejadian skabies pada anak sekolah dasar di Mesir, ditemukan 92 kasus skabies, dimana sekitar $59 \%$ anak-anak yang diteliti berasal dari pedesaan dan $41 \%$ berasal dari perkotaan. ${ }^{14}$ Skabies tidak hanya ditemukan di negara berkembang, tetapi juga ditemukan di negara maju seperti di Jerman. ${ }^{15}$ Kejadian skabies tinggi di negara tropis, terutama pada hunian yang padat, pada penduduk miskin dan terbatasnya akses pengobatan. ${ }^{7}$ Indonesia merupakan salah satu negara tropis dengan angka kejadian skabies yang cukup tinggi. ${ }^{6}$ Hal ini tergambar dari beberapa penelitian tentang skabies yang sudah dilakukan di Indonesia. Berdasarkan penelitian tahun 2007 di beberapa pesantren di Aceh, ditemukan 77 dari 520 santri menderita skabies. ${ }^{16}$ Penelitian yang dilakukan pada tahun 2015 di salah satu puskesmas di Kota Padang juga menemukan kejadian skabies sebanyak 31 kasus. ${ }^{5}$ Penelitian di salah satu pesantren di Jakarta pada tahun 2014 ditemukan 99 dari 192 santri menderita skabies. ${ }^{17}$ Kejadian skabies juga ditemukan di Pulau Sulawesi, hal ini berdasarkan penelitian di salah satu pesantren di Kota Kendari tahun 2017 ditemukan 71 dari 272 santri menderita skabies. ${ }^{6}$

Terdapat beberapa hal yang memengaruhi keberadaan skabies yaitu usia, jenis kelamin, tingkat kebersihan, penggunaan alat pribadi bersama-sama, hunian yang padat, tingkat pendidikan, pengetahuan tentang skabies, budaya setempat, dan sosioekonomi. ${ }^{8}$ Salah satu faktor risikonya adalah hunian yang padat seperti lingkungan asrama, kelompok anak sekolah atau anggota keluarga yang padat. Kepadatan hunian memiliki hubungan yang bermakna dengan kejadian skabies. Tingginya kepadatan hunian meningkatkan risiko kejadian skabies 3,6 kali lebih tinggi dari pada kepadatan hunian yang rendah. Kepadatan hunian yang tinggi akan memengaruhi kelembaban dan suhu ruangan, kelembaban yang tinggi akan memudahkan tungau skabies bertahan hidup lebih lama di luar kulit sehingga akan mempermudah penularan. ${ }^{5}$

Pondok pesantren merupakan sekolah berbasis Islam yang menggunakan asrama sebagai tempat tinggal santri. Kebanyakan asrama pesantren tidak memenuhi luas kamar yang ideal, dimana hunian kamar biasanya lebih padat. Kamar dengan hunian yang padat meningkatkan risiko penularan skabies. Hal tersebut berhubungan dengan meningkatnya kontak antarsantri dan meningkatnya kelembaban ruangan. $^{17}$ Selain tinggal bersama dalam suatu kelompok, skabies juga erat hubunganya dengan 
kebiasaan santri yang suka bertukar pakaian, handuk, sarung, bantal, guling di antara sesama santri. Selain itu, kondisi lingkungan pesantren juga berpengaruh, misalnya pesantren yang berada di lingkungan kumuh, WC dan kamar mandi yang tidak layak. ${ }^{6}$

Tingginya kejadian skabies di pesantren memengaruhi kualitas hidup santri. ${ }^{16}$ Berdasarkan hasil penelitian Purwanto tahun 2016 tentang hubungan penyakit skabies dengan tingkat kualitas hidup santri Pondok Pesantren Al-Muyyad Surakarta, dari 31 penderita skabies terdapat 10 orang yang banyak berpengaruh kepada kualitas hidupnya. ${ }^{18}$ Santri yang paling banyak menderita skabies adalah santri baru karena belum bisa menyesuaikan diri dengan lingkungan, masih sering berganti handuk, pakaian dan mandi bersama yang memudahkan penularan skabies. ${ }^{19}$ Hasil penelitian Nair et al pada tahun 2016, pengaruh skabies terhadap kualitas hidup pada orang dewasa hanya berefek minimal sekitar $51,6 \% .^{10}$

Skabies berdampak pada konsentrasi belajar dan juga kualitas tidur sehingga memengaruhi konsentrasi dan aktivitas sehari-hari. Kualitas tidur juga akan memengaruhi proses belajar, gangguan memori dan kesehatan emosi. ${ }^{19}$ Pasien dengan penyakit kulit akan memengaruhi banyak hal, penyakit kulit dapat menimbulkan rasa cemas, depresi, mudah marah dan rasa malu sehingga berakibat pada isolasi sosial dan ketidak ikut sertaan dalam kegiatan di tempat kerja maupun di sekolah. ${ }^{10}$

Berdasarkan survei awal yang dilakukan oleh penulis diketahui dari hasil, santriwati juga sering bertukar handuk dan menjemur pakaian di dalam ruangan. Kondisi asrama santriwati cukup memprihatinkan, mereka tidur di suatu ruangan dengan kasur yang disusun di lantai. Pada siang hari kasur ditumpuk di sudut ruangan sehingga ruangan dapat dipakai untuk kegiatan lain, berdasarkan kondisi ini maka dilakukan penelitian tentang kualitas hidup santriwati yang menderita skabies.

\section{METODE}

Penelitian ini telah dilakukan di Pondok Pesantren Kecamatan Enam Lingkung, Kabupaten Padang Pariaman pada bulan Juni 2019 sampai Januari 2020. Studi ini bersifat deskriptif dengan disain cross sectional. Pengambilan sampel dilakukan dengan teknik total sampling sehingga didapatkan jumlah sampel sebanyak 32 orang santriwati yang menderita skabies. Penelitian dilakukan dengan pemeriksaan klinis dan kerokan kulit serta proses wawancara yang dipandu kuesioner Modified Dermatology Life Quality Index (mDLQI) yang sudah diterjemahkan dari Bahasa Inggris ke Indonesia.

Data yang diperoleh dari penelitian inii dianalisis secara univariat dengan menggunakan program komputer.

Penelitian ini sudah lolos uji etik dari komite etika penelitian Fakultas Kedokteran Universitas Andalas dengan nomor keterangan lolos kaji etik 067/KEP/FK/2020.

\section{HASIL}

Berdasarkan klinis didapatkan 32 responden menderita skabiesed, tetapi pada kerokan kulit hanya ditemukan satu responden yang positif skabies.

Tabel 1. Karakteristik responden

\begin{tabular}{llrr}
\hline Karakteristik & & $\begin{array}{r}\text { Frekuensi } \\
\text { (f) }\end{array}$ & $\begin{array}{r}\text { Presentase } \\
\text { (\%) }\end{array}$ \\
\hline Umur & 11 tahun & 1 & 3,1 \\
& 12 tahun & 13 & 40,6 \\
& 13 tahun & 17 & 53,1 \\
& 14 tahun & 1 & 3,1 \\
Tingkat & Kelas 1 & 31 & 96,9 \\
pendidikan & Kelas 2 & 1 & 3,1 \\
& Kelas 3 & 0 & 0 \\
& & & \\
\hline
\end{tabular}

Berdasarkan Tabel 1, mayoritas responden berumur 13 tahun dan tingkat pendidikan kelas 1 Madrasah Tsanawiyah. 
Tabel 2. Gambaran kualitas hidup (mDLQI) pada responden

\begin{tabular}{lccc}
\hline \multicolumn{1}{c}{ Kategori } & & $\begin{array}{c}\text { Frekuensi } \\
\text { (f) }\end{array}$ & $\begin{array}{c}\text { Presentasi } \\
\text { (\%) }\end{array}$ \\
\hline Tidak ada pengaruh pada & 4 & 12,5 \\
kualitas hidup & & 20 & 62,5 \\
$\begin{array}{l}\text { Pengaruh kecil } \\
\text { kualitas hidup }\end{array}$ & 8 ada & 0 & 25,5 \\
$\begin{array}{l}\text { Pengaruh sedang pada } \\
\text { kualitas hidup }\end{array}$ & & 0 \\
$\begin{array}{l}\text { Pengaruh besar pada } \\
\text { kualitas hidup }\end{array}$ & & \\
\hline Total & & \\
\hline
\end{tabular}

Berdasarkan Tabel 2, mayoritas penyakit skabies berpengaruh kecil terhadap kualitas hidup responden, diikuti dengan pengaruh sedang, tidak ada pengaruh dan pengaruh besar.

Tabel 3. Distribusi komponen kualitas hidup (mDLQI)

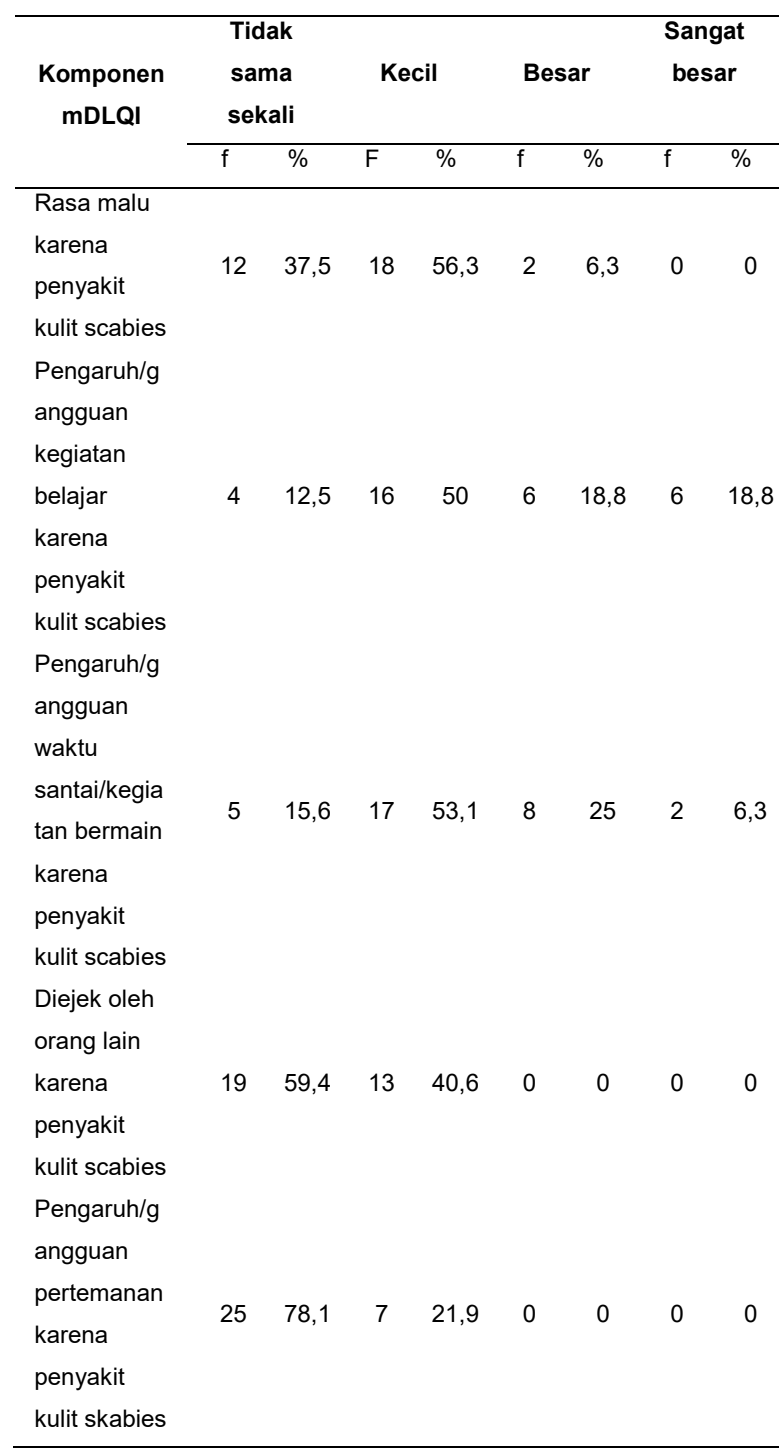

Berdasarkan Tabel 3, komponen kualitas hidup yang paling terganggu adalah kegiatan belajar dan sekolah, sedangkan yang paling tidak terganggu adalah komponen hubungan pertemanan.

\section{PEMBAHASAN}

Pada penelitian ini didapatkan dari 32 santriwati yang menderita skabies di Pondok Pesantren Kecamatan Enam Lingkung, Kabupaten Padang Pariman yang memenuhi kriteria inklusi dan ekslusi. Sedangkan hasil pemeriksaan laboratorium kerokan kulit, dari 32 responden ditemukan 1 parasit tungau Sarcoptes scabiei var hominis dan telurnya. Hasil penelitian ini berbeda dengan penelitian yang dilakukan oleh Kurniati et al, dari 44 sampel ditemukan 18 sampel yang positif skabies dari hasil kerokan kulit. $^{20}$ Perbedaan hasil penelitian ini dengan penelitian sebelumnya kemungkinan disebabkan oleh cara pengambilan sampel kerokan kulit hanya menggunakan object glass, yaitu mengerok kulit penderita dengan ujung dari object glass, kemudian kulit yang sudah dikerok ditempelkan selotip, selanjutnya selotip ditempelkan di object glass. Hal ini bertujuan untuk mengurangi tindakan invasif terhadap responden. Sehingga bisa jadi tidak mencapai terowongan tempat tungau tersebut berada. Namun, jika tidak ditemukan tungau atau produknya hal tersebut tidak dapat menyingkirkan penyakit skabies, karena bisa jadi tungau berada di tempat yang tidak bisa dijangkau saat pengambilan sampel. ${ }^{8}$ Diagnosis skabies dapat juga ditegakkan berdasarkan klinis dengan menemukan 2 dari 4 tanda kardinal yaitu gatal pada malam hari (pruritus nokturna), terdapat sekelompok orang yang menderita penyakit yang sama, terdapat terowongan, papul, vesikel atau pustul di tempat predileksi skabies, dan pada pemeriksaan laboratorium ditemukan tungau. ${ }^{8}$

Berdasarkan hasil penelitian, ditemukan mayoritas responden berumur 13 tahun. Hasil ini sesuai dengan penelitian yang dilakukan oleh Akmal et al pada tahun 2013 di Pondok Pendidikan Islam Darul Ulum, Palarik Air Pacah, Kecamatan Koto Tangah Padang dengan mayoritas umur 13 tahun(26,8\%). ${ }^{4}$ Berdasarkan observasi peneliti selama penelitian, santriwati dengan usia muda dan baru masuk lebih banyak mengalami gejala penyakit skabies. Kejadian 
ini berkaitan dengan santriwati yang belum beradaptasi dengan lingkungan pesantren, sehingga masih sering menggunakan handuk bersama, kain basahan bersama, bertukar pakaian dan menggantung pakaian di dalam ruangan. Selain itu, hal ini juga berkaitan dengan tingkat kerentanan dan pengalaman santri terhadap penyakit tersebut, dimana santriwati dengan umur yang lebih tinggi sudah pernah mengalami penyakit tersebut. Hal ini sesuai dengan teori sebelumnya, bahwa anak-anak merupakan kelompok usia rentan mengalami dampak kesehatan jika sanitasinya tidak terpenuhi dengan baik. ${ }^{21}$

Berdasarkan karakteristik tingkat pendidikan, sebagian besar responden adalah kelas 1 Madrasa Tsanawiyah. Hal ini sesuai dengan hasil penelitian yang dilakukan oleh Aulia et al pada tahun 2017 di Pondok Pesantren Daarul Qur'an Surakarta dengan jumlah responden terbanyak adalah kelas $1(32,9 \%){ }^{22}$

Gambaran kualitas hidup mayoritas penyakit skabies menyebabkan pengaruh kecil terhadap kualitas hidup responden. Hasil penelitian ini sesuai dengan penelitian yang dilakukan oleh Nair et al pada tahun 2016 dengan mayoritas penyakit skabies menyebabkan pengaruh yang kecil terhadap kualitas hidup. ${ }^{10}$ Terdapat beberapa faktor yang memengaruhi perbedaan hasil dengan penelitian sebelumnya. Tingkat kualitas hidup seseorang terkait dengan penyakit tertentu bisa jadi dipengaruhi oleh sudah berapa lama seseorang menderita penyakit tersebut. Hal ini berkaitan dengan tingkat keparahan penyakit, namun keparahan penyakit tidak selalu berkorelasi dengan kualitas hidup. ${ }^{23}$ Dalam penelitian ini, hampir seluruh dari responden adalah kelas 1 Madrasa Tsanawiyah, dimana responden adalah santriwati yang baru masuk dan tinggal di asrama pesantren. Hal ini menunjukkan bahwa penyakit kulit yang diderita oleh santriwati masih berada pada fase awal yang memungkinkan pengaruh yang kecil pada kualitas hidup mereka.

Faktor lain yang berpengaruh adalah tentang persepsi mereka yang menganggap bahwa penyakit kulit sudah biasa terjadi di pesantren. $^{24}$ Hal ini menyebabkan kurangnya rasa malu diantara mereka. Hal ini juga menyebabkan tidak terlalu terganggunya masalah sosial karena sebagian besar dari mereka juga menderita penyakit yang sama. Kondisi pertemanan paling sedikit terpengaruh karena penyakit skabies. $(90 \%))^{10}$

Perbedaan hasil penelitian ini juga dipengaruhi oleh kondisi lingkungan tempat tinggal. Seseorang yang tinggal di lingkungan yang kurang bersih biasanya gangguan kualitas hidupnya karena suatu penyakit lebih rendah. Hal ini mendukung kondisi lingkungan pesantren yang cukup memprihatinkan, sampah berserakan bahkan sampah menumpuk dalam kolam yang tepat berada disamping kelas santriwati, kondisi asrama yang kurang mendapat sinar matahari, dan kondisi kamar mandi yang tidak terlalu luas untuk jumlah santriwati yang cukup banyak. Penyakit tertentu tidak terlalu memengaruhi kualitas hidup mereka, sedangkan seseorang yang tinggal di lingkungan yang cukup bersih kemungkinan gangguan kualitas hidupnya karena suatu penyakit akan lebih tinggi, perkiraaan ini dikonfirmasi oleh data penelitian Jin-gang et al pada tahun $2010 .^{25}$

Komponen kualitas hidup yang paling terganggu atau terpengaruh terhadap santriwati yang menderita skabies di Pondok Pesantren Kecamatan Enam Lingkung, Kabupaten Padang Pariaman adalah kegiatan belajar $(18,8 \%)$ dan komponen yang paling tidak berpengaruh adalah gangguan pertemanan $(78,1 \%)$. Kondisi ini sesuai dengan penelitian yang dilakukan oleh Pragya Ashok Nair et al pada tahun 2016 dengan hasil komponen kegiatan sekolah/belajar $(2,5 \%)$ dan kegiatan bermain/waktu santai $(2,5 \%)$ adalah yang paling terganggu karena penyakit kulit skabies. ${ }^{10}$ Hasil penelitian ini menunjukkan bahwa penyakit kulit skabies paling memengaruhi dan mengganggu kegiatan sekolah atau kegiatan belajar. Berdasarkan hasil wawancara dan kuesioner sebagian besar santriwati mengaku bahwa keluhan gatal pada kulitnya menyebabkan terganggunnya konsentrasi dalam belajar.

Komponen yang paling tidak berpengaruh adalah hubungan pertemanan, hal ini menggambarkan mayoritas santriwati yang menderita skabies di Pondok Pesantren Kecamatan Enam Lingkung, Kabupaten Padang Pariaman tidak ada masalah dengan temantemannya terkait penyakit kulit yang dideritanya. Beradasarkan hasil wawancara hal ini disebabkan persepsi tentang penyakit kulit yang sudah biasa di pesantren dan karena sebagian besar teman-teman 
mereka juga mengalami penyakit yang sama, sehingga mereka mengaku tidak merasa malu denga penyakit tersebut karena tidak ada yang mengejek dan menjauhi mereka karena penyakit tersebut. Hal ini dikonfirmasi oleh data penelitian Pragya Ashok Nair et al pada tahun $2016 .^{10}$

\section{SIMPULAN}

Mayoritas penyakit skabies berpengaruh kecil pada kualitas hidup penderitanya. Kegiatan belajar adalah yang paling terganggu dan terpengaruh oleh penyakit skabies.

\section{SARAN}

Pada penelitian selanjutnya bisa menghubungkan kualitas hidup dengan tingkat keparahan penyakit skabies. Penilaian kualitas hidup sebaiknya dilakukan pada pre dan post pengobatan penyakit skabies. Sebaiknya penelitian dilakukan pada laki-laki dan perempuan, sehingga bisa dijadikan perbandingan.

\section{UCAPAN TERIMA KASIH}

Terimakasih kepada semua pihak yang telah berkontribusi dalam penelitian ini.

\section{DAFTAR PUSTAKA}

1. Chosidow O. Scabies. N Engl J Med. 2006; 354 (16):1718-27.

2. Engelman D, Kiang K, Chosidow O, McCarthy J, Fuller C, Lammie $\mathrm{P}$, et al. Toward the global control of human scabies: Introducing the international alliance for the control of scabies. PLoS Negl Trop Dis. 2013;7(8):5-8.

3. Menaldi SLS. IImu penyakit kulit dan kelamin. Edisi ke-7. Jakarta: Fakultas Kedokteran Universitas Indonesia; 2017.hlm.137-140.

4. Akmal SC, Semiarty R, Gayatri. Hubungan personal hygiene dengan kejadian skabies di pondok pendidikan Islam Darul Ulum, Palarik Air Pacah, Kecamatan Koto Tangah Padang tahun 2013. Jurnal Kesehatan Andalas. 2013; 2 (3): 164-7.

5. Yunita Sari M, Gustia R, Anas E. Faktor-faktor yang berhubungan dengan kejadian skabies di wilayah kerja Puskesmas Lubuk Buaya kota Padang tahun 2015. Jurnal Kesehatan Andalas. 2015;7(1):51-8.
6. Ridwan AR, Sahrudin, Ibrahim K. Hubungan pengetahuan, personal hygiene, dan kepadatan hunian dengan gejala penyakit skabies pada santri di pondok pesantren Darul Muklisin kota Kendari 2017. JIMKESMAS. 2017;2(6):1-8.

7. WHO. Scabies [Internet]. 2019 [diakses 12 Oktober 2019]. Tersedia dari: https://www.who. int/neglected_diseases/diseases/sc

8. Sungkar S, E. Skabies: Etiologi, Patogenesis, pengobatan, pemberantasan, dan pencegahan. Jakarta: Badan Penerbit FKUI; 2016.hlm. 9-18.

9. Irawan Anwar A, Sakka Z, Harfiah. Penyakit Skabies. Dua Satu Press; Universitas Hasanuddin Makasar: 2014.

10. Nair PA, Vora RV, Jivani NB, Gandhi SS. A Study of clinical profile and quality of life in patients with scabies at a rural tertiary care centre. Journal Clin Diagnostic Reasearch. 2016;10(10):1-5.

11. IACS. Skabies. 2014 [diakses 20 Oktober 2016]. Tersedia dari: http;//www.controlscabies.org/ about-scabies/

12. Chandler DJ, Fuller LC. A review of scabies: An infestation more than skin deep. Dermatology. 2019;235:79-90.

13. Karimkhani C, Colombara D V, Drucker AM, Norton SA, Hay R, Engelman D, et al. Article the global burden of scabies: A cross-sectional analysis from the Global Burden of Disease Study 2015. Lancet Infect Dis. 2015; 17 (12): 1247-54.

14. Hegab DS, Kato AM, Kabbash IA, Dabish GM. Scabies among primary schoolchildren in Egypt: Sociomedical environmental study in Kafr ElSheikh administrative area. Clin Cosmet Investig Dermatol. 2015;8:105-11.

15. Ariza L, Brockmann S, Feldmeier H. Investigation of a scabies outbreak in a kindergarten in Constance, Germany. Eur J Clin Microbiol Infect Dis. 2013;32:373-80.

16. Muzakir. Faktor yang Berhubungan Dengan Kejadian Penyakit Skabies Pada Pesantren di Kabupaten Aceh Besar [tesis]. Medan: Fakultas Kedokteran Universitas Sumatera Utara; 2008.

17. Ratnasari AF, Sungkar S. Prevalensi skabies dan faktor-faktor yang berhubungan di pesantren $X$, Jakarta Timur. eJournal Kedokteran Indonesia. 
2014;2(1):7-12.

18. Purwanto NF. Hubungan antara penyakit skabies dengan tingkat kualitas hidup santri di pondok pesantren Al-Muyyad Surakarta [skripsi] Surakarta: Fakultas Kedokteran, Universitas Muhammadiyah. 2016;

19. Merti LGMA. Hubungan skabies dengan prestasi belajar pada santri pondok pesantren di Bandar Lampung [skripsi]. Bandar Lampung: Fakultas Kedokteran, Universitas Lampung; 2017.

20. Kurniati, Zulkarnain I, Listiawan MY. Kesesuaian gambaran klinis patognomonis infestasi skabies dengan kepositifan pemeriksaan dermoskop dan kerokan kulit. Berkala IImu Kesehatan Kulit \& Kelamin. 2014;26(1):14-21.

21. Purnama SG. Buku ajar penyakit berbasis lingkungan. 2016. (diunduh 17 Agustus 2019). Tersedia dari: https://simdos.unud.ac.id/uploads/ file_pendidikan_dir/e1cf67b8122c12a4d2a95d6a c50137ff.pdf
22. Aulia AA, Mulianto N, Widhiati S. Hubungan antara perilaku hidup sehat (pengetahuan, sikap, dan tindakan) dengan kejadian skabies di pondok pesantren Daarul Qur'an Surakarta. Nexus Kedokt Komunitas. 2017;6(1):79-89.

23. Cranenburgh OD Van, Prinsen CAC. Healthrelated assessment in dermatologic practice: relevance and application. Dermatol Clin. 2012; 30(2):323-32.

24. Setyaningrum YI. Skabies penyakit kulit yang terabaikan: Prevalensi, tantangan dan pendidikan sebagai solusi pencegahan.; Proceeding Biology Education Conference: Biology, Science, Enviromental and Learning. 2012;10(1). (diunduh pada 12 Januari 2020) Tersedia dari: https://jurnal.uns.ac.id/prosbi/article/view/6456

25. Jin-gang $A$, Sheng-xiang, Sheng-bin $X$, Jun-min W, Song-mei G, Ying-ying $D$, et al. Quality of life of patients with scabies. JEADV. 2010;24:118791. 